\title{
ANALISIS GAYA KEPEMIMPINAN KEPALA PERPUSTAKAAN UIN SUNAN KALIJAGA YOGYAKARTA
}

\author{
Hadira Latiar *), Nailul Husna **) \\ Universitas Lancang Kuning, Pekanbaru, Indonesia* \\ UIN Sultan Thaha Syaifuddin, Jambi, Indonesia** \\ email: hadira@unilak.ac.id*), naililhusna25@gmail.com**)
}

Naskah diterima: 05 Januari 2020; direvisi: 20 Januari 2020; disetujui: 28 Januari 2020

\begin{abstract}
Abstrak
Perpustakaan UIN Sunan Kalijaga Yogyakarta merupakan salah satu perpustakaan yang mendapat akreditasi "A." Hasil ini tidak akan diperoleh jika seluruh komponen yang terlibat di dalamnya tidak bersinergi untuk mencapai tujuan. Gaya kepemimpinan dari kepala perpustakaan memiliki pengaruh yang penting dalam mensukseskan seluruh kegiatan yang ada di Perpustakaan UIN Sunan Kalijaga Yogyakarta. Penelitian ini bertujuan untuk menganalisis gaya kepemimpinan kepala perpustakaan di Perpustakaan UIN Sunan Kalijaga dengan menggunakan analisis teori gaya kepemimpinan situasional. Metode yang digunakan adalah penelitian kualitatif dangan teknik pengumpulan data wawancara dan observasi. Analisis data dengan mereduksi data, penyajian data dan menarik kesimpulan atau verifikasi. Hasil penelitian menunjukkan bahwa bahwa semua aspek gaya kepemimpinan yang menjadi indikator memenuhi kriteria jenis gaya kepemimpinan situasional. Hal yang dapat dilihat adalah dari sikap tegas, totalitas, semangat dan selalu dapat mampu menyesuaikan diri dengan kondisi kapan dia akan menjadi tegas dan bersikap lunak terhadap kinerjanya dan kinerja bawahnnya.
\end{abstract}

Kata kunci: Gaya kepemimpinan, perpustakaan, pustakawan

\begin{abstract}
The UIN Sunan Kalijaga Yogyakarta Library is one of the libraries that accredited " $A$ ". This result will not be obtained if all the components involved in it do not work together to achieve the goal. The leadership style of the head of the library has an important influence in the success of all activities in the UIN Sunan Kalijaga Yogyakarta Library. This study aims to analyze the leadership style of the library head at Sunan Kalijaga UIN Library using situational leadership theory analysis. The method used is qualitative research with interview and observation data collection techniques. Data analysis by reducing data, presenting data and drawing conclusions or verification. The results showed that all aspects of the leadership style that became an indicator met the criteria for situational leadership style criteria. The thing that can be seen is from a firm attitude, totality, enthusiasm and can always be able to adjust to the conditions when he will be assertive and be soft about his performance and subordinate performance.
\end{abstract}

Keyword: Leadership style, library, librarian 


\section{PENDAHULUAN}

Dalam sebuah organisasi baik profit atau pun non profit, sumber daya manusia (SDM) memiliki peranan penting dalam menunjang organisasi tersebut. Adanya sumber daya manusia di dalam sebuah organisasi berupaya untuk mencapai tujuan organisasi dengan berbagai kreativitas, karya serta bakat yang dimiliki oleh setiap individu. Sekuat dan sesempurna apapun aspek dalam segi ekonomi dan teknologi dalam sebuah organisasi, namun tidak akan tercapai sebuah tujuan yang akan dituju tanpa ada sumber daya manusia. Ada beberapa alasan yang melatarbelakangi mengapa sumber daya manusia memiliki peran yang penting dalam sebuah organisasi, yakni karena sumber daya manusia dapat menjadi sumber yang signifikan bagi keunggulan kompetitif, sumber daya manusia menjadi bagian penting dari strategi organisasi serta cara orangnisasi memperlakukan sumber daya manusianya nantinya akan mempengaruhi kinerja organisasi (Robbins, 2010).

Perpustakaan adalah salah satu organisasi non profit yang begerak dalam jasa pelayanan. Dikatakan sebagai suatu organisasi karena di dalam perpustakaan terdapat berbagai bagian yang memiliki tugas dan fungsi masing-masing dengan tujuan yang sama. Perpustakaan dengan berbagai bagian tersebut diperlukan kemampuan manajemen yang baik agar arah kegiatan yang dilakukan sesuai dengan tujuan yang ingin dicapai. Perpustakaan merupakan dalam satu lembaga pendidikan serta penyedia informasi dapat dikatakan memiliki kinerja yang baik jika segala kegiatannya didukung dengan manajemen yang terarah dan memadai sehingga segala aktivitas lembaga akan mengarah pada upaya pencapaian tujuan yang telah dirumuskan sebelumnya. Selain itu dengan adanya manajemen yang baik untuk menyeimbangkan tujuan-tujuan yang berbeda sehingga dalam pelaksanaanya bisa secara efektif dan efisien. Manajemen diperlukan sebagai alat pengatur langkah-langkah yang harus dlaksanakan oleh seluruh elemenelemen yang ada di perpustakan, sehingga perpustakaan perlu adanya proses perencanaan (planning), pengorganisasian (organizing), kepemimpinan (leadership) dan pengendalian (controlling).
Pada organisasi dibutuhkan satu orang yang diposisikan sebagai pemimpin dalam setiap bagian yang secara terstruktur. Hal tersebut berfungsi untuk menjaga setiap bagan yang ada berjalan sesuai dengan tugas dan fungsi masing-masing serta menjaga sehingga semua tetap pada satu tujuan yang telah ditetapkan sebelumnya.

Husen Umar dalam bukunya Sumber Daya Manusia memaparkan bahwa organisasi hanyalah suatu perkumpulan dari orang-orang serta mesin-mesin yang tidak teratur jika tanpa adanya kepemimpinan. Kepemimpinan merupakan suatu proses pengarahan serta pemberi pengaruh pada kegiatan dari kelompok anggota yang saling berhubungan tugas. Kepemimpinan tidak akan terlepas dari siapa yang memimpin yang disebut pemimpin. Pemimpin adalah orang yang menerapkan prinsip-prinsip serta teknik-teknik yang memastikan motivasi, disilin dan produktifitas jika bekerjasama dengan orang, tugas dan situasi agar dapat mencapai sasaran (Umar, 1999).

Perpustakaan merupakan salah satu organisasi, dimana perpustakaan juga memiliki seorang pemimpin yang disebut sebagai kepala perpustakaan. Keberhasilan suatu organisasi seperti perpustakaan sangat bergantung pada mutu kepemimpinan yang terdapat di dalamnya. Kepemimpinan sendiri dikatakan sebagai kemampuan individu untuk mempengaruhi, memotivasi dan membuat orang lain mampu memberikan kontribusinya demi efektivitas dan keberhasilan organisasi (Yuki, 2010). Dari pendapat di atas disimpulkan bahwa kepemimpinan merupakan suatu cara yang dapat mempengaruhi serta memotivasi orang lain agar orang tersebut mau untuk keberhasilan organisasi. Suatu kepemimpinan akan dapat berjalan jika ada pemimpin. Pemimpin adalah orang yang aktif dalam membuat kegiatan terlaksana, kemudian bertugas sebagai koordinator yang mengusahan dan melaksanakan suatu pekerjaan untuk mencapai tujuan bersama yang telah disepakati (Anoraga, 1992).

Pemimpin pada dasarnya adalah orang yang mampu dalam memberdayakan sumber 
daya manusia yang ada dalam organisasi untuk mencapai suatu tujuan yang telah disepakati bersama. Pada masa saat ini, peran pemimpin dalam sebuah organisasi sangatlah dominan untuk menjembatani setiap masalah-masalah yang dihadapi oleh organisasi. Dalam memimpin sebuah oraganisasi, setiap orang memiliki gaya kepemimpinan yang berbeda dari setiap individu, salah satu yang termasuk ke dalam gaya kepemimpinan adalah gaya kepemimpinan situasional.

Gaya kepemimpinan situasional adalah salah satu teori yang lahir karena teori sifat dan pendekatan prilaku tidak banyak memberikan jawaban dalam gaya kepemimpinan. Hal ini dikarenakan keberhasilan seorang pemimpn tidak hanya dipengaruhi oleh faktor-faktor internal dalam dirinya sendiri, namun faktor eksternal juga berperan seperti visi dan misi organisasi, sifat pekerjaan, lingkungan organisasi serta karakteristik dari individu yang terlibat dalam organisasi tersebut. Dalam gaya ini seorang pemimpin dalam prakteknya memasukkan situasi secara keseluruhan dalam rancangan kegiatan yang akan atau pun sedang dilaksanakan. Penelitian-penelitian yang dilakukan secara lebih lanjut menunjukkan bahwa perilaku kepemimpinan cenderung berbeda-beda dari satu situasi ke situasi lainnya. Dalam kepemimpinan situasional, pemimpin harus mampu melaksanakan diagnosis dengan baik terhadap situasi yang ada sehingga pemimpin harus mampu mengubah-ubah perilaku sesuai dengan situasi dan kondisi serta memperlakukan bawahan sesuai dengan tingkat kematangan yang berbeda-beda (Negara, 2008). Dari penjelasan tersebut dapat disimpulkan bahwa perilaku kepemimpinan situasional cenderung berbedabeda dari situasi satu ke situasi lainnya. Pola perilaku berbeda-beda disesuaikan dengan situasi dan kondisi dari organisasi dan sumber daya manusianya. Dalam gaya kepemimpinan situasional, ada 4 model gaya kepemimpinan situasional menurut Paul Hersey dan Kenneth Blanchard, yakni tipe direktif (telling), tipe konsultatif (selling), tipe partisipatif dan tipe delegatif. Semua model karakteristik ini akan dipaparkan sebagai indikator dalam penelitian yang akan dilakukan peneliti (Negara, 2008).
Perpustakaan UIN Sunan Kalijaga Yogyakarta adalah salah satu perpustakaan yang mendapat predikat A dalam akreditasinya. Hal ini tidak akan terjadi jika seluruh elemen-elemen yang terlibat di dalamnya tidak bekerjasama untuk mencapai tujuan. Gaya kepemimpinan dari pemimpinnya juga memiliki pengaruh yang penting dalam mensukseskan seluruh kegiatan yang ada di Perpustakaan UIN Sunan Kalijaga Yogyakarta. Hal ini menjadikan penulis memilih Perpustakaan UIN Sunan Kalijaga Yogyakarta untuk diteliti dalam hal gaya kepemimpinan dari pemimpin pada periode saat ini. Penelitian ini berjudul "Analisis Gaya Kepemimpinan Kepala Perpustakaan UIN Sunan Kalijaga Yogyakarta." Analisis dalam penelitian ini akan menggunakan empat model gaya kepemimpianan situasional di atas untuk mengukur apakah di dalam organisasi Perpustakaan UIN Sunan Kalijaga Yogyakarta menganut sistem gaya kepemimpinan situasional atau pun sebaliknya.

Penelitian relevan terkait objek penelitian, pertama penelitian yang dilakukan oleh Rahmah (Rahmah \& Marlini, 2017) bahwa peran kepemimpinan di perguruan tinggi dapat dilihat dari beberapa indikator melalui pengembangan visi, menetapkan arah dan strategi perpustakaan, mengkomunikasikan tujuan, memberikan motivasi pustakawan dan staf, menciptakan perubahan yang diinginkan pemustaka. Kedua, penelitian yang dilakukan oleh Widyastuti dkk (Widiyastuti et al., 2002) bahwa apraktik kepemimpinan koordinator perpustakaan Balai Arkeologi Yogyakarta ini mengkombinasikan antara gaya kepemimpinan affiliative dan democratic. Ketiga, penelitan Igriza (Igriza, 2017) mengungkapkan bahwa terjadinya globalisasi informasi, pola kepemimpinan yang baik di perpustakaan sangat dibutuhkan. Pola kepemimpinan berdasarkan emotional intelligence yang di dalamnya terdiri dari visioner, pembimbing, afiliatif, demokratis, penentu kecepatan, dan memerintah bisa menjadi pilihan pola kepemimpinan yang diterapkan di perpustakaan.

Dari tinjauan pustaka tersebut terdapat perbedaan dengan penelitian ini, yaitu teori 
yang digunakan. Teori yang digunakan pada penelitian ini adalah teori gaya kepemimpinan sedangkan penelitian terdahulu menggunakan teori Total Quality Management (TQM), dan praktik kepemimpinan. Dengan demikian, penelitian ini bersifat orisinil dan berbeda dengan penelitian terdahulu.

Adapun rumusan masalah dalam penelitian ini adalah bagaimana gaya kepemimpinan kepala perpustakaan UIN Sunan Kalijaga Yogyakarta?

Tujuan penelitian ini adalah untuk menganalisis gaya kepemimpinan kepala perpustakaan di Perpustakaan UIN Sunan Kalijaga Yogyakarta.

\section{METODE}

Metode yang digunakan dalam penelitian ini adalah menggunakan metode penelitian kualitatif. Penelitian kualitatif adalah penelitian yang bermaksud untuk memahami fenomena tentang apa yang dialami oleh subyek penelitian misalnya perilaku, persepsi, motivasi, tindakan dan lain-lain. Secara holistik dengan cara deskripsi dalam bentuk kata-kata dan bahasa, pada suatu konteks khusus yang alamiah dan memanfaatkan berbagai metode alamiah (Moleong, 2010).

Penelitian ini dilaksanakan di Perpustakaan UIN Sunan Kalijaya Yogyakarta yang beralamat di Jalan Marsda Adisucipto, Demangan, Gondokusuman.

Subjek dalam penelitian ini adalah pustakawan di Perpustakaan UIN Sunan Kalijaga Yogyakarta. Sementara itu objek dari penelitian ini adalah Analisis Model Kepemimpinan Kepala Perpustakaan UIN Sunan Kalijaga Yogyakarta.

Dalam penelitian ini data primer yang diperoleh melalui hasil observasi mengenai hal-hal yang berkaitan dengan penelitian ini dan wawancara dengan pustakawan bekerja di perpustakaan. Data sekunder untuk memperoleh data meliputi geografis, sejarah perpustakaan, keadaan perpustakaan, dan data-data yang berkaitan dengan penelitian.

Teknik pengumpulan data menggunakan metode observasi, ini untuk mendapatkan informasi mengenai model kepemimpinan kepala Perpustakaan UIN Sunan Kalijaga Yogyakarta. Dalam melakukan wawancara, selain harus membawa instrumen sebagai pedoman untuk wawancara, penulis juga dapat menggunakan alat bantu seperti tape recorder, gambar, brosur dan material lain yang dapat membantu pelaksanaan wawancara menjadi lancer (Sugiyono, 2010). Metode pengumpulan data dengan wawancara ini penulis lakukan dalam rangka untuk memperoleh data melalui keterangan-keterangan dari orang-orang yang diwawancarai. Metode ini penulis gunakan untuk memperoleh data responden secara langsung seperti pustakawan yang ada di Perpustakaan UIN Sunan Kalijaga.

Sementara itu, untuk memproses analisis dalam model Miles dan Huberman ini dapat melalui tiga proses, yakni:

a. Reduksi Data

Reduksi data merupakan suatu bentuk analisis yang menajamkan, menggolongkan, mengarahkan, membuang yang tidak perlu, dan mengorganisasi data dengan cara sedemikian rupa hingga kesimpulankesimpulan finalnya dapat ditarik dan diverifikasi.

b. Penyajian Data

Penyajian data merupakan sekumpulan informasi tersusun yang memberi kemungkinan adanya penarikan kesimpulan dan pengambilan tindakan.

c. Menarik Kesimpulan / Verifikasi

Penarikan kesimpulan merupakan sebagian dari satu kegiatan dari konfigurasi yang utuh. Kesimpulankesimpulan juga diverifikasi selama penelitian berlangsung. 


\section{HASIL DAN PEMBAHASAN}

Organisasi tidak akan bisa berkembang jika tanpa ada pemimpin yang mampu mengarahkan dan mengkoordinir bawahannya. Tanpa pemimpin dalam sebuah organisasi maka tujuan didirikannya organisasi tersebut tidak akan bisa tercapai. Meskipun di dalam organisasi tersebut terdapat banyak sumber daya manusia namun hal itu tidak akan bisa menjadi jaminan untuk mewujudkan tujuan organisasi. Hal ini disebabkan karena setiap manusia mempunyai keinginan dan emosional yang berbeda sehingga jika sebuah organisasi tidak ada pemimpin maka akan terjadi tumpang tindih antar karyawan karena tidak ada yang mengkoordinirnya.

Perpustakaan yang termasuk bagian dari organisasi juga sangat membutuhkan seorang pemimpin. Apalagi perpustakaan perguruan tinggi yang pemustakanya merupakan civitas akademika tentunya mereka mengharapkan adanya pelayanan prima dari perpustakaan guna menunjang kebutuhan mereka akan informasi yang dibutuhkan. Pustakawan sebagai petugas di perpustakaan diharapkan mampu untuk bekerja secara profesional agar dapat memberikan pelayanan yang baik kepada pemustaka. Pelayanan yang baik dari perpustakaan akan terwujud jika adanya kerjasama antara pimpinan, pustakawan dan staf. Pemimpin yang baik adalah pemimpin yang mampu mengarahkan, memotivasi serta mengkoordinir setiap elemen yang ada di perpustakaan agar dapat menyelesaikan pekerjaannya dengan baik.

Seorang pemimpin mempunyai gaya kepemimpinannya masing-masing. Pemimpin yang dapat dikatakan efektif adalah pemimpin yang mampu mengkondisikan gaya kepemimpinannya dari berbagai macam situasi yang ada. Pemimpin tidak hanya menggunakan satu gaya kepemimpinannya saja di semua keadaan atau dalam kondisi apapun. Untuk mengetahui bagaimana gaya kepemimpinan seorang pemimpin dalam setiap situasi dan kondisi yang terjadi dapat dianalisis dengan menggunakan teori model kepemimpinan situasional. Teori ini dapat digunakan untuk menganalisis bagaimana gaya kepemimpinan seseorang dengan melihat dari beberapa aspek yaitu gaya pemberitahu (telling), gaya penjual (selling), gaya partisipatif (participating), gaya pendelegasi (delegating). Pada penelitian ini untuk melihat bagaimana gaya kepemimpinan kepala perpustakaan UIN Sunan Kalijaga, penulis juga menggunakan analisis teori gaya kepemimpinan situasional. Adapun hasil wawancara yang didapatkan oleh penulis akan dijelaskan dibawah ini:

\section{Gaya Pemberitahu}

Gaya pemberitahu merupakan gaya di mana seorang pemimpin memberikan instruksi yang jelas kepada bawahannya. Setiap tugas yang akan diberikan akan diinstruksikan bagaimana cara mengerjakannya dengan baik. Selain mengintruksikan dalam gaya ini pemimpin juga mengawasi pekerjaan yang dilakukan bawahan. Berdasarkan hasil wawancara, gaya ini juga diterapkan oleh Kepala Perpustakaan UIN Sunan Kalijaga sebagaimana yang telah dikemukan oleh pustakawan yang berinisial WA, beliau mengatakan sebagai berikut:

"menurut saya kepala perpustakaan selalu memberi instruksi dan arahan yang jelas kepada kami bawahannya, baik itu dalam bentuk formal maupun non formal. Kami juga kalau tidak tahu dengan tugas-tugas atau pekerjaan yang dikasih, akan bertanya kembali ke kepala perpustakaan, dan kepala perpustakaan pun akan menjelaskan ulang. Kalau sudah menginstruksikan sesuatu, biasanya ibu kepala tidak lepas tangan, dia akan selalu mengontrol dan mengawasi pekerjaan kami. Jadi kami merasa di perhatiin sehingga akan menyelesaikan tugas tersebut dengan baik".

Hal serupa juga sama dengan apa yang dikatakan pustakawan yang berinisial AS, beliau mengatakan sebagai berikut:

"kalau saya lihat kepemimpinan kepala perpustakaan sangat welcome, beliau bersedia menerima setiap saran-saran dari kami.Selain itu instruksi-instruksi yang diberikan juga cukup jelas baik itu melalui struktur keorganisasian maupun bersifat person. Dalam memberikan tugas saya melihat kepala ini dia akan selalu mengecek dan mengontrol pekerjaan bawahannya. Misalnya ada pekerjaan yang harus 
diselesaikan, kepala akan selalu mengontrol pekerjaan itu hingga sampai selesai."

Seorang pemimpin yang menggunakan gaya ini biasanya mereka juga akan membantu bawahan yang tergolong masih baru untuk menghasilkan kinerja yang maksimal dan juga akan berusaha untuk menyediakan pondasi yang solid bagi kepuasan dan kesuksesan bawahan dimasa yang akan datang. Hal ini tampaknya juga yang dilakukan oleh Kepala Perpustakaan UIN Sunan Kalijaga. Kepala perpustakaan akan memberitahu bagaimana cara kerja di perpustakaan bagi bawahan yang tergolong masih baru. Hal ini sama dengan apa yang diungkapkan oleh salah satu pustakawan yang berinisial SR, beliau mengatakan:

"Ya... saya melihat ibu kepala ini dia orangnya tidak pelit ilmu. Ibu ini mau berbagi ilmu yang dia punya apalagi dalam bidang perpustakaan. Dia selalu membantu orang yang baru kerja disini untuk mampu menyelesaikan tugasnya dengan maksimal. Kalaupun ibu sibuk, biasanya ibu akan memilih salah satu dari bawahannya untuk mengajari mereka yang baru bekerja. Dan saya lihat dalam memilih orang ibu kepala tidak sembarangan, dia memang benarbenar memilih orang yang ahli dalam bidang tersebut. Misalnya ya untuk mahasiswa partime tentunya dia kan masih baru, dan ibu kepala itu akan mengutus orang untuk membimbingnya, maklm jadwa ibu sangat padat jadi biasanya dia menunjuk salah satu dari kami yang sudah lama untuk membimbing mereka. Tentunya hal ini akan berdampak pada masa depan mahasiswa tersebut jika dibimbing dengan orang yang berkompeten dalam bidangnya."

Berdasarkan hasil wawancara di atas menunjukkan bahwa pada teori model kepemimpinan situasional dilihat dari gaya pemberitahu, kepala perpustakaan UIN Sunan Kalijaga telah menerapkan gaya ini kepada bawahannya. Hal ini terlihat dari beberapa hasil wawancara pada pustakawan mereka mengatakan kepala perpustakaan selalu memberikan instruksi yang jelas serta selalu mengawasi dan mengontrol pekerjaan yang dilakukan bawahannya.

\section{Gaya Penjual}

Gaya penjual ini merupakan gaya seorang pemimpin yang selalu menyediakan pengarahan, selalu melakukan komunikasi dengan bawahannya. Setiap tugas yang diberikan kepada bawahan pemimpin akan selalu memberi arahan terhadap tugas tersebut. Memberitahu bagaiman alur yang harus dikerjakan dari tugas yang diberikan. Dalam pemberian tugas pemimpin mengkomunikasikannya dengan baik dengan bawahan, sehingga akan tercipta situasi yang nyaman dan bawahan akan merasa lebih dihargai jika penyampaian dalam pemberian tugas disampaikan dengan komunikasi yang baik. Hal senada juga sama seperti yang disampaikan oleh pustakawan yang berinisial MO, beliau mengatakan:

"Biasanya dalam memberikan tugas kepala perpustakaan akan melakukan pengarahan terlebih dahulu kepada bawahannya bagaimana skema dalam tugas tersebut. Dan biasanya dalam mengkomunikasikannya saya rasa kepala perpustakaan dalam menyampaikannya cukup baik. Terkadang malah menyampaikannya dibarengi dengan guyonan-guyonan, jadi kami bawahan ini menerima tugas dari ibu juga senang. Kan kalau memberikan tugas dengan cara bentak-bentak itu kurang menyenangkan sehingga kami juga malas-malasan untuk menyelesaikan tugas tersebut dengan baik."

Hal senada juga dikatakan oleh pustakawan yang berinisial TA, beliau mengatakan:

"Kami biasanya sebelum di beri tugas itu, kepala akan memberikan pengarahan terlebih dahulu, tentang bagaimana tugas tersebut, apa yang harus kami kerjakan. Komunikasi yang terjalin antara kepala dengan bawahannya saya melihat cukup baik. Selama penyelesaian tugas pemimpin akan selalu berkomunikasi dengan kami paling tidak menanyakan sebatas mana pekerjaan sudah terselesaikan. Kalau begitu kan kami juga merasa senang, karena ada perhatian dari pimpinan."

Pada gaya ini seorang pemimpin biasanya akan juga memberikan motivasi kepada bawahannya. Selain memotivasi pada gaya ini seorang pemimpin juga akan menunjukkan perilaku dukungan yang bertujuan untuk 
memancing rasa percaya diri bawahannya. Sikap memancing percaya diri bawahan akan berdampak pada penyelesaian tugas dengan baik. Memotivasi dan memberikan dukungan kepada bawahan ini juga diterapkan oleh kepala perpustakaan UIN Sunan Kalijaga kepada bawahannya. Hal ini terlihat dari hasil wawancara dengan pustakawan yang berinisial WA, beliau mengatakan :

"kalau menurut saya kepala perpustakaan disini dia sangat memotivasi bawahannya. Misalnya kalau kami merasa tidak mampu terhada pekerjaan, biasanya kepala perpus akan meyakinkan kami kalau kami pasti bisa melakukan pekerjaan tersebut. Bukan memotivasi saja saya lihat, kepala perpus juga mendukung setiap kami melakukan pekerjaan, walaupun salah akan diarahkan dengan baik. Hal tersebut akan lebih membuat kami untuk percaya diri dalam menyelesaikan tugas-tugas kami. Apalagi pada waktu akan diadakan IcoASL banyak pustakawan yang tidak percaya diri bahwa perpustakaan mampu mengadakan acara itu, maklum itu kan acara international. Tetapi ibu kepala selalu memotivasi dan meyakinkan para bawahannya sehingga acara tersebut dapat terselenggara."

Berdasarkan hasil wawancara di atas menunjukkan bahwa pada teori model kepemimpinan situasional dilihat dari gaya penjual, kepala perpustakaan UIN Sunan Kalijaga telah menerapkan gaya ini kepada bawahannya. Hal ini terlihat dari beberapa hasil wawancara pada pustakawan mereka mengatakan bahwa kepala perpustakaan di Perpustakaan UIN Sunan Kalijaga mampu memotivasi dan memberi dukungan kepada bawahan sehingga bawahan merasa percaya diri dalam meyelesaikan tugas yang diberikan.

\section{Gaya Partisipatif}

Gaya kepemimpinan partisipatif ini lebih kepada pemimpin mendorong untuk saling berbagi gagasasan, memfasilitasi pekerjaan bawahan serta melakukan komunikasi terbuka dengan bawahan. Realita yang terjadi di perpustakaan UIN Sunan Kalijaga menurut beberapa sumber menyatakan bahwa kepemimpinan pemimpin pada periode saat ini menganut gaya partisipatif. Hal ini sesuai dengan hasil wawancara yang dilakukan kepada salah Ibu WA selaku pustakawan dan Kaur menyatakan bahwa:

"Biasanya setiap ide dan gagasan yang berkaitan dengan kemajuan perpustakaan dikomunikasikan bersama sehingga semua berhak memberikan kontribusi pemikirannya. Ibu kepala juga memberikan motivasi pada bawahan walaupun tidak secara langsung, misalnya memuji bawahan dengan memberikan koreksi jika ada kesalahan. Komunikasi juga cukup terbuka, rapat evaluasi biasanya dilakukan dua minggu sekali untuk mengetahui masukan dan saran dari masing-masing kour. Terkait dengan kepribadian, Ibu kepala merupakan pribadi yang tegas dan dapat menyesuaikan diri dengan keadaan, disiplin dan totalitas dalam melaksanakan tugasnya, sehingga bawahan merasa termotivasi ".

Selain Ibu WA, hal yang sama juga diungkapkan oleh Ibu SR yang menjabat sebagai Kepala Bidang Layanan di Perpustakaan UIN Sunan Kalijaga, Beliau mengungkapkan bahwa:

"Kepemimpinan kepala perpustakaan UIN sangat welcome (terbuka), Beliau bersedia menerima saran dan kritik dari bawahan baik secara langsung maupun tidak langsung. Motiviasi yang biasanya diberikan dalam kata-kata penyemangat kepada bawahannya pada setiap kesempatan serta komunikasi antar pemimpin dan bawahan selalu berjalan terbuka."

Hal senada juga diungkapkan oleh beberapa kepala di bawah kepala perpustakaan bahwa kepemimpinan saat ini juga dipengaruhi oleh kepribadian sang pemimpin yang tegas, disiplin, totalitas dan kepribadiannya juga disesuaikan dengan keadaan yang dialami perpustakaan. Namun, ada hasil wawancara yang menyatakan bahwa pemimpin jarang berada di perpustakaan seperti yang diungkapkan oleh Ibu WA:

"Karena kesibukan yang tinggi dari kepala perpustakaan, Beliau jadi jarang terjun ke lapangan menghampiri bawahannya, namun 
hal itu biasa dilakukan sehingga biasanya dialkukan rapat evaluasi yang biasanya dilakukan dua minggu sekali untuk mengetahui masukan dan daran dari masing-masing Kaur."

Hal yang sama juga diungkapkan oleh salah satu pustakawan yang berinisial TN, mengungkapkan:

"Setiap ada permasalahan dapat dibahas baik secara langsung melalui kaur-kaur bidang masing-masing dibawa dalam rapat evaluasi. Karena kepala perpustakaan jarang meninjau langsung di lapangan sehingga kurang terjadi keakraban yang intensif pada staf bawahan."

Dari hasil wawancara tersebut dan diakitkan dengan gaya kepemimpinan situasional, maka dapat disimpulkan bahwa kepemimpinan saat ini menganut kememimpinan situasional, namun kurang dalam hal pimpinan terjun ke lapangan untuk meninjau langsung kinerja staf sehingga kurang terjadinya keakraban yang intensif pada bawahan, namun pemimpin tetap memprhatikan, mengarahkan, serta mengkoodinasikan para bawahannya bagaimana capaian-capaian yang telah dilaksanakan selama pimpinan tidak berada di tempat melalui rapat evaluasi.

\section{Gaya Pendelegasi}

Gaya pendelegasi adalah Gaya pemimpin yang cenderung mengalihkan tanggung jawab atas proses pembuatan keputusan dan pelaksanaannya. Realita yang ada di Perpustakaan UIN Sunan Kalijaga berdasarkan wawancara dengan beberapa informan ditemukan hasil bahwa gaya pendelegasian juga dianut oleh pemimpin perpustakaan periode saat ini. Seperti yang diungkapkan oleh salah satu pustakawan yang berinisial SR berikut ini:

"Jika ada kegiatan biasanya pimpinan mendelegasikan kepada bawahan yang ditunjuk berdasarkan kompetensinya sebagai perwakilan atau menghandel kegiatan yang dimaksud. Pada intinya, karakter kepribadian dari Beliau merupakan pribadi yang tegas, penuh semangat dan totalitas dalam melaksanakan tugasnya sebagai kepala perpustakaan UIN Sunan Kalijaga."

Hal senada juga diungkapkan oleh salah satu pustakwan lainnya yang berinisial WA.

"Jika kepala perpustakaan tidak dapat menghadiri undangan atau even maka dapat mendelegasikanya kepada pihak-pihak yang berkompeten, kemudian hasil dari kegiatan bisa diinformasikan atau dibahas bersama.

Dari hasil wawancara di atas, dilihat bahwa sikap gaya kepemimpinan delegasi juga dianutnya, dimana beliau akan menugaskan staf atau pustakawan yang memang berkompeten dalam bidang tersebut untuk mewakilkannya. Kemudian nantinya hasil dari pendelegasian tersebut akan dibahas dan diinformasikan kepada seluruh jajaran bawahan, hal ini untuk selalu memperbaharui pengetahuan semua bawahannya. Karena karakternya yang totalitas serta tegas dan mampu bersikap sesuai dengan kondisi menjadikannya menganut gaya kepemimpinan situasional dalam mempimpin perpustakaan UIN Sunan Kaijaga.

\section{SIMPULAN}

Dari hasil analisis teori gaya kepemimpinan kepala Perpustakaan UIN Sunan Kalijaga dapat disimpulkan bahwa kepemimpinan di UIN Sunan Kalijaga menganut sistem gaya kepemimpinan situasional dengan mengukurnya melalui empat aspek yakni gaya pemberitahu, gaya penjual, gaya partisipatif dan gaya delegatif. Wawancara yang dilakukan oleh peneliti terhadap 5 (lima) orang informan dengan pedoman wawancara menggunakan pengukuran empat aspek di atas menunjukkan bahwa semua aspek tersebut memenuhi kriteria jenis gaya kepemimpinan situasional. Hal yang dapat dilihat adalah dari sikap tegas, totalitas, semangat dan selalu dapat mampu menyesuaikan diri dengan kondisi kapan dia akan menjadi tegas dan bersikap lunak terhadap kinerjanya dan kinerja bawahnnya. Sebagai rekomendasi pihak Perpustakaan UIN 
Sunan Kalijaga Yogyakarta, sebaiknya kepala perpustakaan lebih sering meninjau perpustakaan agar terjalin kerjasama dan keakraban yang lebih dalam untuk mewujudkan tujuan bersama.

\section{DAFTAR PUSTAKA}

Anoraga, P. (1992). Psikologi Kepemimpinan. Rineka Cipta.

Igriza, M. (2017). Kepemimpinan di Perpustakaan Berdasarkan Emotional Intellegience dalam Menghadapi Globalisasi Informasi. Khizanah Al-Hikmah: Jurnal Ilmu Perpustakaan, Informasi, Dan Kearsipan, 5(1), 113-120. https://doi.org/10.24252/kah.v5i $1 \mathrm{a} 10$

Moleong, L. J. (2010). Metode Penelitian Kualitatif. Remaja Rosdakarya.

Negara, L. A. (2008). Kepemimpinan Dalam Organisasi: Modul Pendidikan dan Pelatihan Kepemimpinan Tingkat Tiga. Lembaga Administrasi Negara RI.
Rahmah, E., \& Marlini. (2017). Peran Kepemimpinan Dalam Mendorong Organisasi Untuk Mengimplementasikan PrinsipPrinsip Total Quality Management (TQM) Di Perpustakaan Universitas Negeri Padang. Pustaka Budaya, 4(2), 43-57.

Robbins, C. (2010). Manajemen. Erlanga.

Sugiyono. (2010). Memahami Penelitian Kualitatif. Alfabeta.

Umar, H. (1999). Kepemimpinan Dalam Organisasi. Gramedia Pustaka Utama.

Widiyastuti, Kurniawan, E., Setyowati, R., \& Lestariningsih, E. D. (2002). Analisis Praktik Kepemimpinan Koordinator Perpustakaan Balai Arkeologi Daerah Istimewa Yogyakarta Menurut Pandangan Maha Kumaran. Pustaka Budaya, 4(2), 19-99.

Yuki, G. (2010). Kepemimpinan Dalam Organisasi. Indeks. 